\title{
Effect of bleaching agents on black tooth stains caused by chromogenic bacteria: 10 years follow-up case report
}

\author{
Efeito de agentes clareadores na pigmentação extrínseca causada por bactérias cromogênicas: 10 anos de \\ acompanhamento de caso
}

\author{
Susana MORIMOTO' \\ (iD) ORCID iD 0000-0002-6458-1954 \\ Denis Yudi NAGASE2 \\ (iD) ORCID ID 0000-0002-1078-1547 \\ Tamara Kerber TEDESCO ${ }^{1}$ \\ (D) ORCID iD 0000-0003-0794-1578 \\ Bárbara Thayara Barral MORAES 1 \\ (D) ORCID ID 0000-0001-7994-8707 \\ Newton SESMA 3 \\ (iD) ORCID iD 0000-0001-5044-1742
}

\begin{abstract}
Some microorganisms are associated with the formation and deposition of pigmentation on dental surfaces, and its localization, intensity and recurrence persistence can introduce aesthetic disorders. Carbamide peroxide is a bleaching agent that also presents antimicrobial properties. This case report addresses a ten-year clinical follow-up, showing a possible influence of a bleaching procedure protocol on alterations of oral microbiota. Although a bleaching treatment does not have the purpose to alter the oral microbiota, a drastic reduction and recurrence of black tooth stains was observed in this case.
\end{abstract}

Indexing terms: Bacteria. Esthetics, dental. Tooth bleaching.

\section{RESUMO}

Alguns microrganismos são associados com a formação e deposição de pigmentação sobre a superfície dental, sendo que a localização, intensidade e persistência de recorrência dessas pigmentações podem levar a problemas estéticos. O peróxido de carbamida é um agente clareador no qual também mostra propriedades antimicrobianas. Este relato de caso trata de um acompanhamento de dez anos mostrando uma possível influência de um clareamento dental em alterações na microbiota. Embora o clareamento dental não tenha a finalidade de alterar a microbiota bucal, neste relato foi observado a redução na quantidade e recorrência de manchas extrínsecas negras.

Termos de indexação: Bactérias. Estética dentária. Clareamento dental.

\section{INTRODUCTION}

Black extrinsic tooth stains has been under the scope of clinical evidence in the current days, and could be associated with aesthetics issues and caries, being a concern for millions of children and adults [1-9]. Among the bacteria pigments, the black ones are the most studied and occur as a line or bands mainly on the lingual surface near the gingival margin. These types of black stains can be continuous, localized or in dotted lines form, being strongly adhered, making its removal difficult by the use of a simple toothpaste and toothbrush, with a possible recurrence after its clearing [4-5]. Microscopically, they are characterized by a special biofilm, being its microbiota relatively stable and homogeneous, since it is composed by microorganisms of a same morphological type (approximately 90\% positive cocci) and the presence of calcification markedly differing from the ultrastructural appearance of a normal biofilm [9].

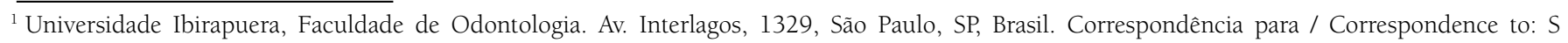
MORIMOTO. E-mail: <susanamorimoto@gmail.com>

${ }^{2}$ Universidade de São Paulo, Departamento de Odontologia Restauradora. São Paulo, SP, Brasil.

${ }^{3}$ Universidade de São Paulo, Departamento de Prótese Dentária. São Paulo, SP, Brasil.

$\checkmark v \boldsymbol{v}$

Como citar este artigo / How to cite this article

Morimoto S, Nagase DY, Tedesco TK, Moraes BTB, Sesma N. Effect of bleaching agents on black tooth stains caused by chromogenic bacteria: 10 years follow-up case report. RGO, Rev Gaúch Odontol. 2018;66(2):00-00. http://dx.doi.org/10.1590/1981-8637201800020000143457
} 
A recent study has confirmed the existence of iron in black stains. It was the first time the genes of bacteria in black extrinsic tooth stains were accessed and associated with iron, and thereby, the association between the metabolic pathway of microbiota and this oral phenomenon could be established [1].

External dental bleaching can be used to remove extrinsic and intrinsic tooth stains. Dental bleaching has been a hot topic because there are controversial whether tooth-bleaching agents exert negative influence on oral health, and the benefits concerning aesthetic results [1024]. Tooth bleaching agents contain oxidizing agents, which serve as the main part of bleaching agents because of its release of effective bleaching component. The active ingredient of tooth bleaching is hydrogen peroxide $\left(\mathrm{H}_{2} \mathrm{O}_{2}\right)$, and the dentist-supervised at-home bleaching with trays associated with $1-10 \%$ hydrogen peroxide or $10-22 \%$ carbamide peroxide has become widely accepted by patients and dentists, due to the simplicity, effectiveness, less post operative sensitivity and low cost, when compared to in-office treatment [10-14]. Hydrogen peroxide and carbamide peroxide also show antimicrobial properties, and controversially, clinical and laboratorial researches have been focused on bleaching agents' effects on the growth of oral microbes and the formation of biofilms, and their influence on oral health [15-24]. Although a bleaching treatment does not have the purpose to alter the oral microbiota, a change in the dentist-supervised at-home bleaching protocol can help in the decreasing of recurrence of black tooth stains and, especially, with the unsightly appearance of stains that reach the buccal surface of the anterior teeth.

However, to the best of our knowledge, there is no previous studies that proposed a treatment for the reduction/elimination of the chromogenic bacteria, when aesthetics problems are present. In the same way, there are no longitudinal reports about the impact of the elimination or reduction of chromogenic bacteria on the oral cavity.

Thus, the aim of the present report was to demonstrate-a different protocol for tooth bleaching, discussing a possible alteration in the oral microbiota with a ten-year clinical follow-up.

\section{CASE REPORT}

A 45-year-old male patient, non-smoker, complaining of the presence of black extrinsic stains on the teeth was referred to Dental Clinic of the Military Police (São Paulo- Brazil). He reported having such pigmentations for about 15 years; however, in the last two years he had undergone teeth cleaning performed by a dentist every 20-40 days since he was unhappy with the unsightly appearance of the pigmentation, and wanted to have a brighter teeth free of stains. Patient stated that his diet was rich in vegetables, and low-carbohydrate ingestion. When questioned about other members of family, it was reported that his wife also had these pigments in a smaller proportion.

During clinical examination, black stains affecting all teeth and surfaces, in the form of lines, dots or a continuous or broken narrow band adjacent the free gingiva, interproximal spaces and bypassing even composite resin restorations, were detected (Figures 1, 2, 3 and 4).

After treatment plan approval by signing the informed consent form, a teeth cleaning with ultrasound and a sodium bicarbonate jet was performed. Then, a dentist-supervised at-home bleaching with trays and $10 \%$ carbamide peroxide (Fórmula \& Ação, São Paulo, SP, Brasil.) was established. The standard protocol consists in the application of a drop of the bleaching gel on teeth buccal surfaces for 20 days at night. However, two changes in this protocol were proposed: Besides the application on the buccal surfaces, the patient should also include a bleaching gel drop onto the lingual surfaces, thus all teeth should receive the bleaching gel, including teeth with prosthetic crowns. After treatment, the patient reported being satisfied with the bleaching and he did not present new stains.

Reassessment was planned every three months up for a year after the bleaching treatment was performed. No relapse of the pigmentation, even before professional tooth prophylaxis was observed in this period (Figures 5, 6,7 and 8). After that, the patient had to return annually for clinical examination and tooth cleaning. Only small areas with black spots could be seen. Thus, after a ten-year clinical follow-up, there were small areas of black extrinsic stains recurring periodically. Nevertheless, this relapse was not present with the same intensity and frequency that that seen prior bleaching (Figures 9, 10, 11 and 12). Furthermore, the patient did not report discomfort with this new stains. No new bleaching was performed in the follow-up period. In the same way, there was not repair or replace of restorations by presence of dental caries, neither periodontal disease was detected. 


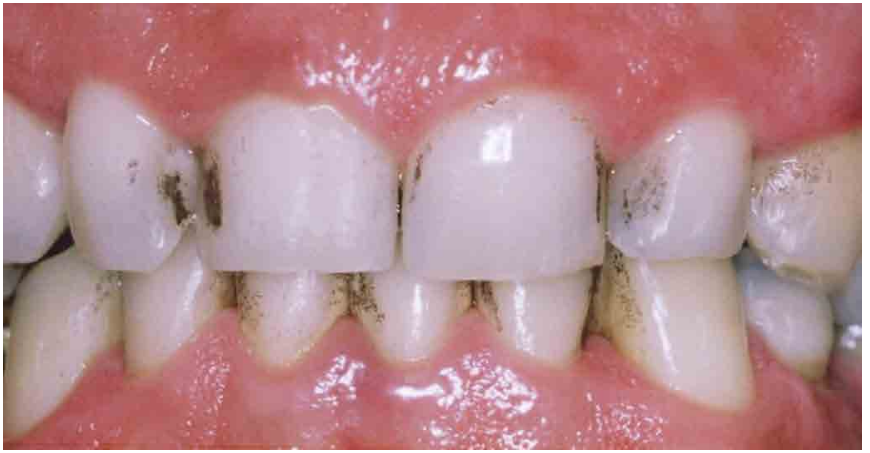

Figure 1. Buccal view of upper and lower anterior teeth before the bleaching procedure. Black stains occur in form of lines or bands, continuous or dotted, near the gingival margins and interproximal area, reaching all teeth.

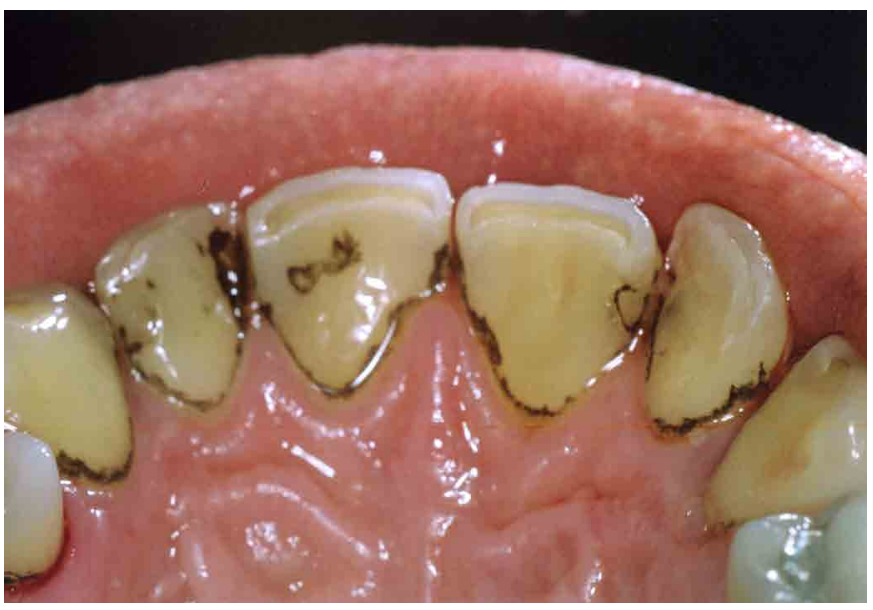

Figure 2. Occlusal view before the bleaching procedure. The stains circumvent the gingival margins, proximal surfaces and composite resin restorations (distal and mesial surface of 11 and 12 , respectively).

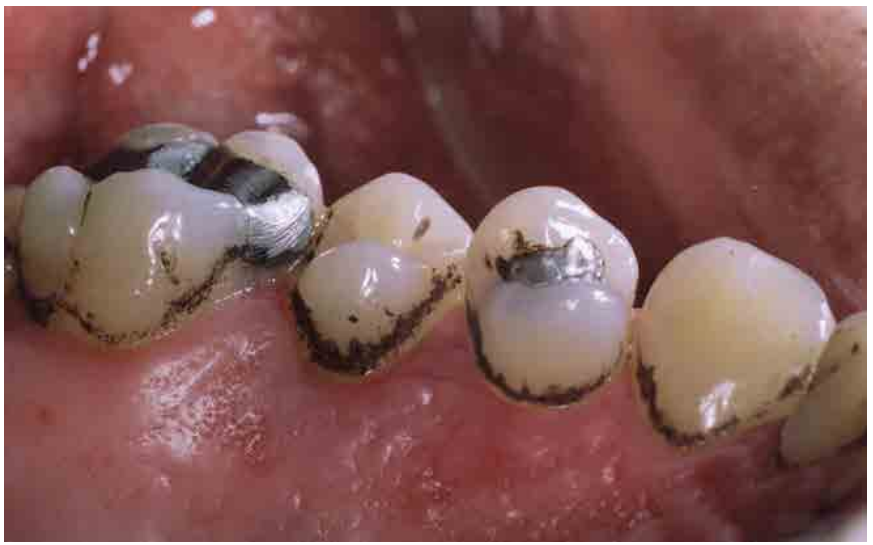

Figure 3. Occlusal-palatal view of the upper-right teeth before the bleaching procedure. Palatal surfaces with high black stain accumulation on all teeth.

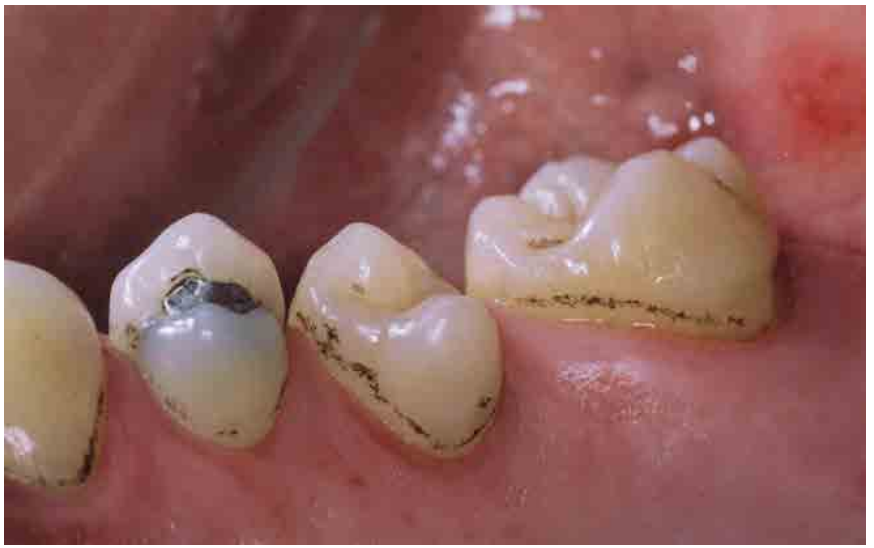

Figure 4. Occlusal-palatal view of the upper left teeth before the bleaching procedure. Palatal surfaces with less black stain accumulation, but with a typical chromogenic bacteria pigmentation pattern.

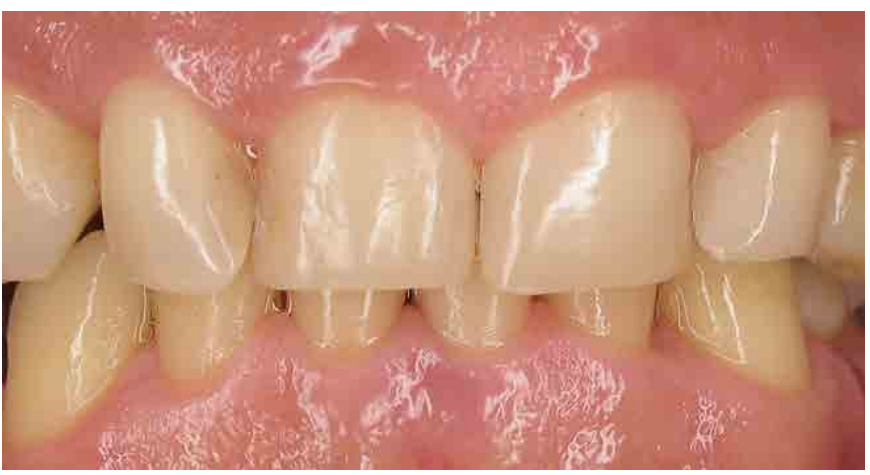

Figure 5. Buccal view of anterior teeth after dentist-supervised at-home bleaching with trays and carbamide peroxide $10 \%$. One-year follow-up.

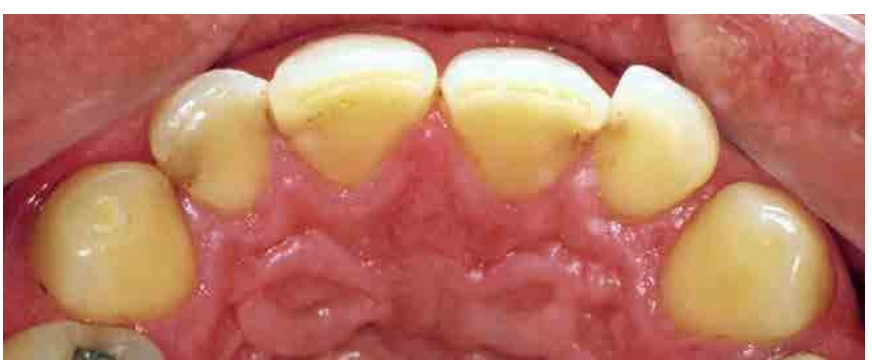

Figure 6. Palatal view after dentist-supervised at-home bleaching with trays and carbamide peroxide $10 \%$. One-year follow-up

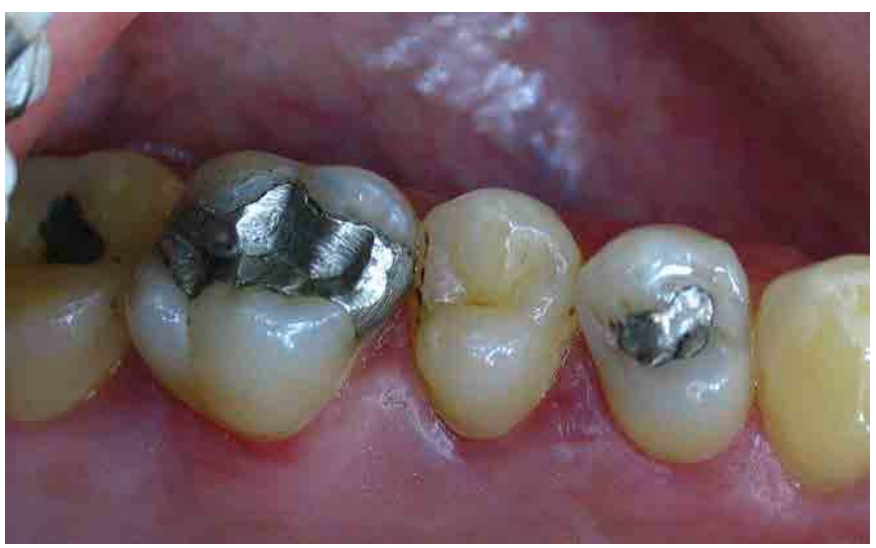

Figure 7. Occlusal-palatal view of upper right teeth after dentist-supervised at-home bleaching with trays and carbamide peroxide 10\%. One-year follow-up. 


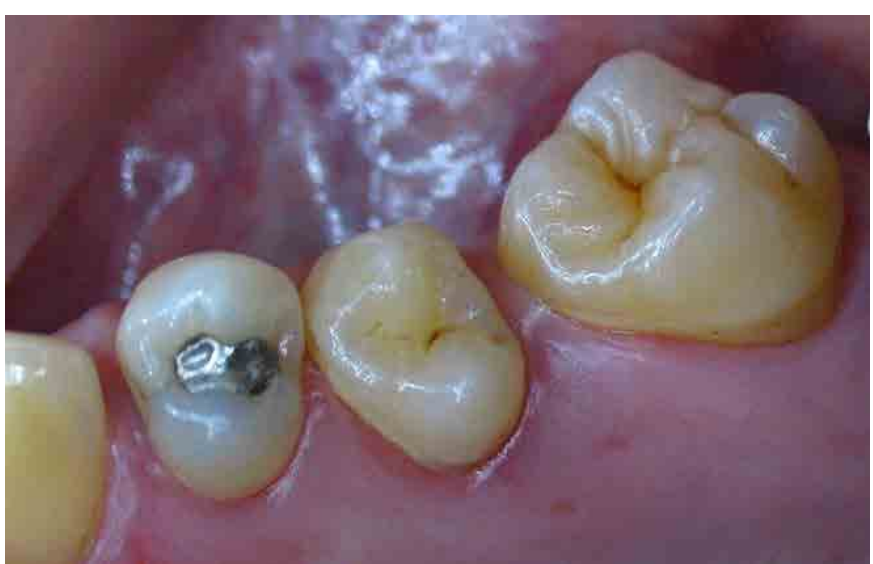

Figure 8. Occlusal-palatal view of the upper left teeth after dentist-supervised at-home bleaching with trays and carbamide peroxide 10\%. One-year follow-up.



Figure 9. Buccal view of anterior teeth after dentist-supervised at-home bleaching with trays and carbamide peroxide $10 \%$. Ten-year follow-up.

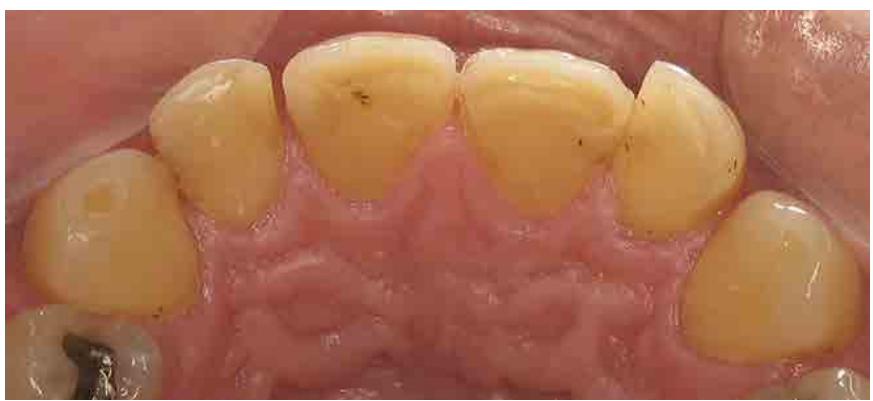

Figure 10. Palatal view after dentist-supervised at-home bleaching with trays and carbamide peroxide $10 \%$. Ten-year follow-up

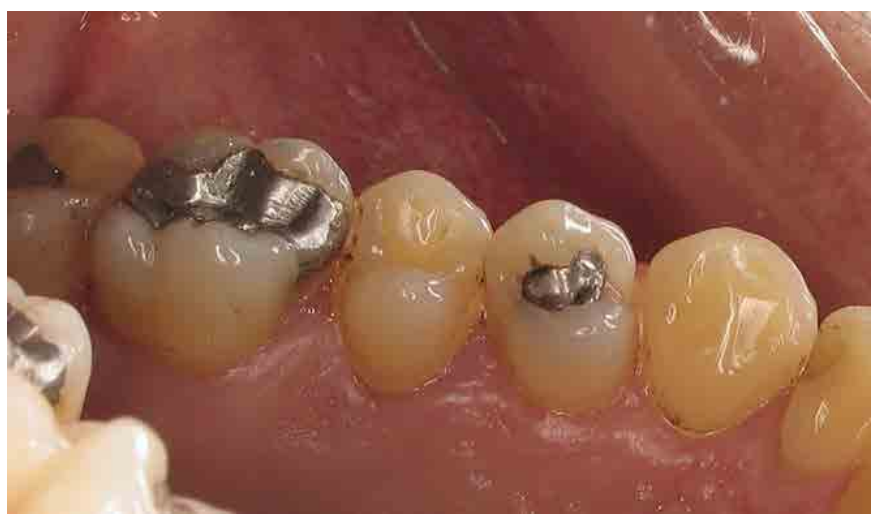

Figure 11. Occlusal-palatal view of upper right teeth after dentist-supervised athome bleaching with trays and carbamide peroxide $10 \%$. Ten-year follow-up.

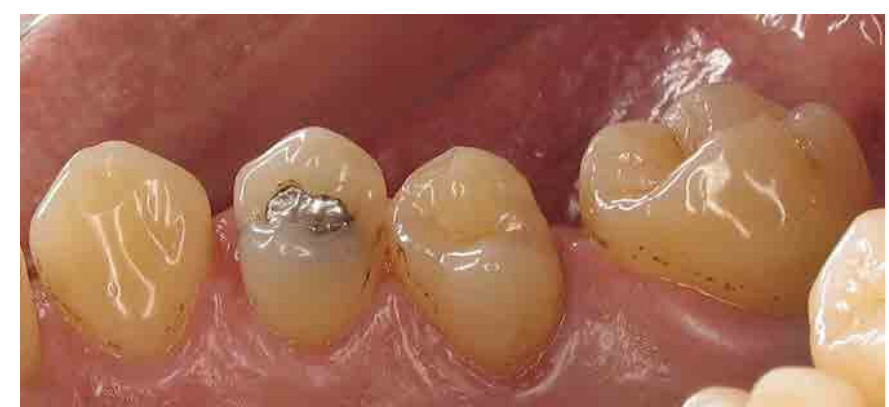

Figure 12. Occlusal-palatal view of the upper left teeth after dentist-supervised at-home bleaching with trays and carbamide peroxide $10 \%$. Ten-year follow-up

\section{DISCUSSION}

The presence of pigmentation from chromogenic bacteria is a relatively common in day-to-day practice finding. There is no consensus in the literature about its etiology and even epidemiology [1-9], with their basic features remainining as a mystery [2]. In the same way, it is not established if these bacteria are responsible only for the pigmentation, or if they are influencing other outcomes when associated with pathologies (periodontal disease or caries) in the oral cavity [2,3,5-8]. Therefore, the conduction of longitudinal follow-up studies is necessary.

A positive association between the presence of black stains and lower prevalence of caries has been previously suggested $[3,7,8]$. However, some studies have not found this correlation [6]. This phenomenon has been confirmed by a reduction of $51 \%$ in the caries prevalence when black stains were present, leading to consider the presence of such stains as a protective factor against caries lesion development [7]. The biofilm of black stains is considered differentiated by containing more iron salts and high concentrations of calcium and phosphate $[1,2,5-7]$. The black pigments are probably insoluble salts formed from the reaction between sulfuric acid, produced by bacteria, with the iron present in saliva and gingival exudate, comprising ferrous sulphate and originating pigmented deposits on the tooth structure.-Bacterial composition shows a significantly increase in the count of Actinomyces naes/undii and reduction of Lactobacillus sp. and $F$. Nucleatum. These factors may explain the association of black stains with the low prevalence of caries lesions [2].

On the other hand, the prevalence of black stains seems to be divergent among studies, ranging from $3.48 \%$ to $20 \%$, which can affect both young people and adults, though a higher frequency is observed among 
children $[6,7]$. When this type of staining occurs on primary teeth, and since they will be replaced by permanent successors and the salivary maturation during children's transitions to an adult one, pigment's disappearance can be observed [9]. Although there is a report of a greater predisposition in women [4], this pigmentation seems not to show differences between genders $[6,9]$. In relation to localization, no differences are verified between anterior and posterior teeth, but it seems to be more common on the lingual surfaces near the gingival margins [9]. Other chromogenic microorganisms such as fungi Penicillium and Aspergillus can cause green and fluorescent stains and, since they develop only in the presence of light, are usually found on the upper anterior teeth [4].

The staining intensity and number of affected teeth by pigments vary among individuals, but usually several teeth are affected. Poor oral hygiene intensifies the degree of staining, however, the pigmentation by chromogenic bacteria can occur, even if more discreetly and at longer intervals, in patients with good oral hygiene [4]. A betterconducted anamnesis including targeted questions and clinical assessment of pigmentation common features, support the diagnosis process, recommendations for patients and both therapeutic and preventive management that should be performed.

Although with limited action, recommendations on the use of the called "bleaching" toothpastes could be an interesting and safe method in controlling pigmentation from chromogens microorganisms since they work in the prevention and elimination of biofilm and stains, promoting and apparent whitening. Toothpastes with peroxide contain might also bring good results, whereas these substances are effective in removing extrinsic stains by pigments oxidation [14]. On the other hand, the use of toothpastes having only high degrees of abrasives is not as effective in the stains control near the gingival margins and interdental spaces, due to restricted toothbrush and toothpaste access in these regions, the most affected by chromogenic bacteria.

In the present case report, a change in the usual of dentist-supervised at-home bleaching protocol was recommended [10-14], using the bleaching agent in all teeth on both buccal and lingual surfaces. The intention was far from only tooth bleaching but also offering an antibacterial and antimicrobial action showed by carbamide and hydrogen peroxide and their oxygen release, having an effect on Gram-positive and Gram-negative bacteria $[12,16,19]$.
The carbamide peroxide partly degrades into hydrogen peroxide (3 to $5 \%$ ) and urea (7 to $10 \%$ ) $[20,21]$. Peroxide inhibits some microorganisms' growth and metabolism, being the anaerobic organisms particularly sensitive to oxygen molecules. Nevertheless, the peroxide cytotoxicity may also be attributed to its effect on the cell membrane and bacterial DNA [20]. Antibacterial and antimicrobial activity is given by the oxygen release and enzymes actions, such as the catalases and peroxidases. However, catalases are not as effective in high-concentration peroxide, allowing a prolonged action, which favors its role as bleaching agents $[14,20,21,24]$.

Therefore, if used appropriately, the $\mathrm{H}_{2} \mathrm{O}_{2}$ exposure from bleaching is minimal. Furthermore, it is essentially limited to the oral cavity and is incapable of reaching a systemic level to induce toxicity because of the effective metabolic defensive mechanisms. Its decomposition in the oral cavity occurs in a few minutes, since saliva, fluoride and remineralizing agents have a key role in minimizing the changes caused by bleaching products $[14,17]$.

Peroxide for bleaching can modify, even temporarily, when used at the appropriate time and concentration, the enamel, dentin, caries lesions, cement, pulp, dental materials or the oral microbiota $[14-16,20,21,23]$. The tooth surface and restorative materials, which have received previous bleaching treatment, become more porous, softening or cracking after the procedures. However, this is a transient condition, due to the remineralization process by the saliva $[11,14,15]$. Also, these porosity can modify the adsorption of salivary proteins and, consequently, the formation and composition of biofilm and bacterial adhesion $[21,23]$. The reduction in rates of gingivitis and biofilm at the end of bleaching procedures, have been reported in clinical studies $[12,16]$. The most commonly seen side effects are teeth sensitivity and gingival irritation, which are usually mild to moderate and transient. Data accumulated during the last two decades demonstrate that, there is no evidence of significant health risks associated with tooth whitening when used properly, being a safety and effective treatment [14].

In addition to peroxides other components could be present in the formulation of a bleaching agent. Glycerin, fluorine and desensitizing agents, which are not active in bleaching treatment, can also act on the biofilm. Glycerin causes dehydration even to the tooth structure; fluorine is known to be a bactericidal/bacteriostatic product, acting by inhibiting the bacterial enzyme metabolism. The effects of desensitizing agents (bactericidal / bacteriostatic) on 
oral biofilm, such as potassium nitrate or sodium citrate, present in the composition of certain bleaching agents should also be investigated [13,17,19-21]. Another factor to be considered is the $\mathrm{pH}$, as bleaching agents usually have acid levels (ranging from 4.6 to 7.4), which might also influence the oral microbiota [21].

This off-label treatment protocol was proposed after patient's complaints regarding the constant recurrence and, especially, unsightly appearance of stains involving the buccal surfaces of anterior teeth. Pigments' reduction after 10 years of bleaching suggests a change in the oral microbiota and, in this case, a desired and effective effect. However, scientific literature has not been focused on this. Alterations in microbiota could eliminate bacterial residents, those normal and non-pathogenic and, subsequently, allow the proliferation, installation, and colonization of pathogenic bacteria. This phenomenon is one of the questions that this study cannot answer. However, in this ten-year clinical follow-up case report the presence of caries lesion and/or periodontal disease was not detected. Restorations replacement were performed only due to fracture or aesthetic reasons.

Positive and negative impact of bleaching on tooth structure, mucosa, restorative materials, gums and biofilm levels, have been investigated in order to support bleaching techniques, making them safer procedures [11,12,14-16]. Further long follow-up studies aiming at evaluating the effect of bleaching agents on oral microbiota are needed, focusing on microorganisms' cultures before and after bleaching procedures.

\section{REFERENCES}

1. Zhang $F$, Li Y, Xun Z, Zhang Q, Liu H, Chen F. A preliminary study on the relationship between iron and black extrinsic tooth stain in children. Lett Appl Microbiol. 2017 Jun;64(6):424-429. doi: 10.1111/lam.12728

2. Li Y, Zou CG, Fu Y, Li Y, Zhou Q, Liu B, Zhang Z, Liu J. Oral microbial community typing of caries and pigment in primary dentition. BMC Genomics. 2016;17:558. doi: 10.1186/s12864016-2891-z

3. Li Y, Zhang Q, Zhang F, Liu R, Liu H, Chen F. Analysis of the microbiota of black stain in the primary dentition. PLoS One. 2015 Sep 4;10(9):e0137030. doi: 10.1371/journal.pone.0137030

4. Hattab FN, Qudeimat MA, al-Rimawi HS. Dental discoloration: an overview. J Esthet Dent. 1999; 11(6):291-310.

5. Heinrich-Weltzien R, Bartsch B, Eick S. Dental caries and microbiota in children with black stain and non-discoloured dental plaque. Caries Res. 2014;48(2):118-25. doi: 10.1159/000353469

\section{CONCLUSIONS}

This ten-year clinical follow-up after tooth bleaching allows to affirm that there is a change in the expression pattern of stains caused by chromogenic bacteria, showing the influence of bleaching agents on the oral microbiota. This could lead to a significant reduction in the amount of black extrinsic stains. This therapy is safe for those cases where chromogenic staining bacteria are causing aesthetic discomfort in patients.

\section{Collaborators}

S MORIMOTO, substantive intellectual contributions, substantial contributions to conception and design, clinical care, drafting the article, revising it critically for important intellectual content and final approval of the version to be published. N SESMA, substantive intellectual contributions, clinical care, drafting the article and final approval of the version to be published. BTB MORAES, substantial contributions to conception and design, revising it critically for important intellectual content and final approval of the version to be published. TK TEDESCO, substantive intellectual contributions, substantial contributions to conception and design, revising it critically for important intellectual content and final approval of the version to be published. DY NAGASE, substantive intellectual contributions, revising it critically for important intellectual content and final approval of the version to be published.

6. Gasparetto A, Conrado CA, Maciel SM, Miyamoto EY, Chicarelli M, Zanata RL. Prevalence of black tooth stains and dental caries in Brazilian schoolchildren. Braz Dent J 2003;14(3):157-61. doi: 10.1590/S0103-64402003000300003

7. Franca-Pinto CC, Cenci MS, Correa MB, Romano AR, Peres MA, Peres KG, et al. Association between black stains and dental caries in primary teeth: findings from a Brazilian populationbased birth cohort. Caries Res. 2012;46(2):170-6. doi: $10.1159 / 000337280$

8. López Martínez TM, Goettems ML, Azevedo MS, Correa MB, Demarco FF, Romano AR. Black stains and dental caries in Brazilian schoolchildren: a cross-sectional study. Braz Oral Res. 2016;30(1). Epub Oct 10, 2016. doi: 10.1590/1807-3107BOR2016.vol30.0110

9. Gallardo VP, Cencílio CP. Tinción cromógena: un problema habitual en la clínica pediátrica. An Pediatr. (Barc) 2005;62(3):25860. doi: 10.1157/13071841

10. Haywood VB, Sword RJ. Tooth bleaching questions answered Br Dent J. 2017;223(5):369-380. doi: 10.1038/sj.bdj.2017.767 
11. Carey CM. Tooth whitening: what we now know. J. Evid Based Dent Pract. 2014;14(Suppl):70-6. doi: 10.1016/j. jebdp.2014.02.006

12. Reinhardt JW, Eivins SE, Swift EJJr, Denehy GE. A clinical study of nightguard vital bleaching. Quintessence Int. 1993;24(6):37984.

13. Haywood VB, Caughman WF, Frazier KB, Myers ML. Tray delivery of potassium nitrate-fluoride to reduce bleaching sensitivity. Quintessence Int. 2001;32(2):105-9.

14. Li Y, Greenwall L. Safety issues of tooth whitening using peroxide-based materials. Br Dent J. 2013;215(1):29-34. doi: 10.1038/sj.bdj.2013.629

15. Zalkind M, Arwaz JR, Goldman A, Rotstein I. Surface morphology changes in human enamel, dentin and cementum following bleaching: a scanning electron microscopy study. Endod Dent Traumatol. 1996;12(2):82-8.

16. Alkmin YT, Sartorelli R, Florio FM, Basting RT. Comparative study of the effects of two bleaching agents on oral microbiota. Oper Dent. 2005;30(4):417-23.

17. Leonard RH Jr, Austin SM, Haywood VB, Bentley CD. Change in $\mathrm{pH}$ of plaque and $10 \%$ carbamide peroxide solution during nightguard vital bleaching treatment. Quintessence Int. 1994;25(12):819-23.

18. Flaitz CM, Hicks MJ. Effects of carbamide peroxide whitening agents on enamel surfaces and caries-like lesion formation: an SEM and polarized light microscopic in vitro study. ASDC J Dent Child. 1996;63(4):249-56.
19. Bentley $\mathrm{CD}$, Leonard RH, Crawford JJ. Effect of whitening agents containing carbamide peroxide on cariogenic bacteria. J Esthet Dent. 2000;12(1):33-7.

20. Gurgan S, Bolay S, Alaçam R. Antibacterial activity of $10 \%$ carbamide peroxide bleaching agents. J Endod. 1996;22(7):3567. doi: 10.1016/S0099-2399(96)80217-2

21. Napimoga $\mathbf{M H}$, de Oliveira R, Reis AF, Gonçalves RB, Giannini $M$. In vitro antimicrobial activity of peroxide-based bleaching agents. Quintessence Int. 2007;38(6):e329-33.

22. Gurgan S, Bolay S, Alacam R. In vitro adherence of bacteria to bleached or unbleached enamel surfaces. J Oral Rehabil. 1997;24(8):624-7. doi: 10.1111/j.1365-2842.1997.tb00383.x

23. Steinberg D, Mor C, Dogan H, Zacks B, Rotstein I. Effect of salivary biofilm on the adherence of oral bacteria to bleached and non-bleached restorative material. Dent Mater. 1999;15(1):1420. doi: 10.1016/S0109-5641(99)90026-X

24. Franz-Montan M, Ramacciato JC, Rodrigues JA, Marchi GM, Rosalen PL, Groppo FC. The effect of combined bleaching techniques on oral microbiota. Indian J Dent Res. 2009;20(3):3047.

Received on: 28/6/2017

Final version resubmitted on: 20/11/2017

Approved on: 19/12/2017 